\title{
Tidskriften Arkiv bjuder in till dialog och diskussion om klass och jämlikhet
}

Som start på vad vi hoppas kan bli en hel serie med artiklar i ämnet publicerar vi i detta nummer en nyskriven artikel om klassbegreppet författad av en av deltagarna i Katalys klassprojekt, Mikael Stigendal. I projektet har han bidragit till boken Klass i Sverige. Ojämlikheten, makten och politiken i det 2I: a århundradet med en studie av Malmö. Stigendals nya artikel är en kritisk-realistisk genomgång av frågan om klassbegreppets analytiska värde och värdebas i klassisk samhällsvetenskaplig teori. Den växte fram ur diskussioner i mellanrummen under klassprojektets gemensamma brainstormning men låg utanför dess huvudsakliga inriktning.

\section{co}

Klass, klassanalys, klassbegrepp och ett nästan outsinligt uttryck för olika klasspraktiker har under senare år åter hamnat i förgrunden i både den internationella och svenska offentligheten. Inte minst har beständiga men olikartade, motsägelsefulla kroppsliga och könade erfarenheter samt ojämlikheten i mänskliga levnadsförhållanden - klasskillnader satt fart på en diskussion om klass bortom klassturismens enkla, färgblinda subjektivitet. Istället har den samtida klasstrukturen, dess yttringar och framtid i nuet åter hamnat i fokus för både spontana och institutionella ansträngningar. Efter förmåga har denna tidskrift i tidigare nummer uppmärksammat fenomenet i till exempel nummer I och 3 i den nya serien från 2013 och framåt, efterföljaren till Arkiv för studier $i$ arbetarrörelsens historia (1972-2009). Klass fortsätter att engagera, nya "massor" träder fram, materien förändras och fördjupas. 
Året - 202I - har i detta avseende börjat bra. Med denna inbjudan knyter tidskriften an till den rörelse det fackliga idéinstitutet Katalys har initierat och eldar på. Sprungen ur det gångna årtiondets mest omfattande kraftsamling för att lyfta besvärliga samtidsfrågor har ett trettiotal fristående samhällsforskare, några (fackliga) utredare och en enda journalist nyligen sammanställt resultatet av sina bemödanden i den omfångsrika boken Klass $i$ Sverige.

Boken gavs ut på Arkiv förlag i januari 202I och skapade omedelbart stort pådrag i sammanhang där det vanligtvis talas tämligen tyst om klass, makt och jämlikhet: Dagens Nyheter med en DN Debatt-artikel söndagen den 24 januari, signerad bokens redaktörer Daniel Suhonen, Göran Therborn och Jesper Weithz jämte 33 av dess övriga författare samt därtill en bokrecension på tidningens kultursida precis en vecka senare (av Leonidas Aretakis 3I januari). Vidare recensioner i Göteborgs-Posten (Bo Rothstein 8 februari) och Sveriges Radio (Magnus Henreksson i diskussion med Daniel Suhonen 26 januari) och inte att förglömma ett fyrsidigt flerfärgsreportage i Svenska Dagbladet Kultur söndagen den 3I januari med historiska Arkiv-röster som Jenny Andersson (nr 82-83 200I) och Åsa Linderborg ( $\mathrm{nr} 88-89$ 2003) tillsammans med den officiella S-tankesmedjan Tidens Daniel Färm och Katalys Daniel Suhonen plus Göran Therborn. Nästan två veckor senare konstaterar en understreckare i samma tidning att "Klassperspektiven är tillbaka i debatten" (Sebastian Lönnlöv i3 februari). Ytterligare en vecka senare är det dags igen för Dagens Nyheter med ett personporträtt av Daniel Suhonen (20 februari).

Mer förväntade reaktioner var förstås Lina Stenbergs ledarkommentar i Aftonbladet (25 januari) och Kajsa Ekis Ekmans stort uppslagna kulturartikel i samma tidning (28 januari). I båda dessa artiklar stod klassboken central. Även Anneli Jordahl i samma tidning nämnde avslutningsvis boken i artikeln "Sadism i det blödande klassamhället" (3 februari). På gränsen till storstadspressen återfinns en recension i Uppsala Nya Tidning (3I januari) samt en i heldigitala Arbetet (Timbros Caspian Rehbinder 28 januari). I landsortspressen är det mestadels i S-märkta tidningar boken anmälts: Dala-Demokraten, Norrländska Socialdemokraten, Sydöstran, Västerbottens Folkblad. 
Marken för denna uppmärksamhet bereddes redan 2018 av Arkiv förlags bok på samma tema: Kapitalet, överheten och alla vi andra av just Göran Therborn. Han var emellertid inte ensam, Katalys samlade detta år och det föregående (20I7) i sitt klassprojekt också många yngre forskare och andra intresserade till konferenser, seminarier och välbesökta möten på ABF-huset i Stockholm. Alla deltagare blev inte skribenter i den rapportserie Katalys pytsade ut under våren 2018. Intresset har dock hållit i sig och ser ut att fortsätta. Ett intryck som förstärks inte minst på grund av den pedagogiska studiehandledning David Örfelth och Daniel Suhonen har utarbetat till och inkluderat i boken Klass $i$ Sverige (s. 653-672). Klassboken och dess många författare är idag således inte på något sätt ensamma om att utifrån sina vetenskapliga analyser ställa klass, klassförtryck, klassojämlikheter och andra klassmarkörer i centrum. Uttryckt i något annorlunda termer har också en nationell och gedigen statlig utredning kommit fram till liknande resultat: SOU 2020:46, En gemensam angelägenhet från Jämlikhetskommissionen med Per Molander som huvudansvarig (se också Arkiv nr II 2019).

Klassboken om 752 sidor är visserligen något tunnare än den statliga utredningen men vassare i sina spetsformuleringar och har som framgår ovan provocerat till debatt och polemik. Den statliga utredningen med sin inriktning på uppmaningar till omedelbara fördelningspolitiska ingrepp skiljer sig naturligtvis något från klassbokens efterlysning av bredare djupdykningar och förankring av jämlikhetsdrivande processer och åtgärder. Klassboken argumenterar för behovet av klasspolitik utan att närmare gå in på existensen av aktuella klasstrider och förutsättningarna för de organiserade klassernas och skiktintressenas olika dagspolitiska vägval.

Tilläggas bör att i dagens svenska samhälle - både i nationens centrum och dess periferi - finns också flera lokala exempel på initiativ med en inriktning inte olik såväl klassbokens som den statliga utredningens. En jämlikhetsrörelse har vuxit fram också i Sverige - om den blir lång- eller kortvarig, central eller lokal, är för tidigt att säga något bestämt om. Klassboken med bidrag från forskare runt om i Sverige är ett tecken på denna växande rörelse. Med tunga vetenskapliga belägg hävdar dessa forskare att systematiska skillnader i så olika saker som arbetsförhållanden, barns 
födelsevikt, dödlighet, jämställdhet, kapitalmakt (också i omsorg, skola och vård), livslängd - för att ta några centrala exempel - mellan olika samhällsgrupper i en befolkning - från arbetarklass via professioner till överheten - till mycket stor del kan förklaras inte bara av förväntningar om kommande börsutdelningar utan av sociala bestämningsfaktorer: ursprung och uppväxt, familje- och arbetsförhållanden - habitus lägger eventuellt den mer sofistikerade till som vet hur klass görs dagligen och stundligen långt bortom resebroschyrernas glättigheter "i vardagen".

Det finns många frågor kring klass bärkraft och relevans som söker sina svar. Kunskap om klass och skikt har hittills stått i förgrunden för ovan nämnda analyser och undersökningar, ett vetande med konsekvenser på många olika tillämpningsområden. Sökandet går vidare. Vandringen från gårdagens småfolk och underklass till dagens medelklass är bara ett exempel. Klassallianser och klassamarbeten är två andra exempel, klassförräderi, klasskamp, klassmothugg (läs "hat"), och klassmotsättningar andra teman som delvis legat utanför den hittills existerande klassramen samtidigt som dessa ämnen tangerats i uppföljande inlägg och synpunkter.

\section{$\cos$}

Tidskriftens redaktion emotser med spänning både en och två eftertankar, ja gärna ännu fler. Vår förhoppning är nämligen att Stigendals artikel ska följas av ytterligare ett antal texter med tämligen skiftande upplägg och teman.

Analytiska, begreppsliga, empiriska, metodologiska, pragmatiska och teoretiska inspel är mycket välkomna framöver. Om dessa utläggningar är i de klassiska klasstänkarnas - eller några andra vetenskapliga celebriteters - anda, eller till synes helt egensinniga, bekymrar redaktionen föga. Redaktionen söker naturligtvis artiklar med klass och kvalitet. Den förbehåller sig rätten att refusera insända utkast efter redaktionell och oberoende utomstående granskning. 


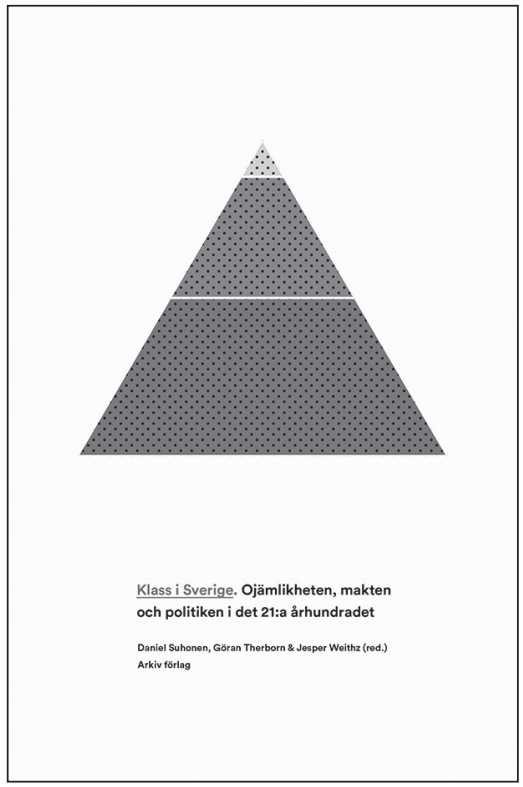

\section{Klass i Sverige Ojämlikheten, makten och politiken i det 21:a århundradet}

Daniel Suhonen, Göran Therborn \& Jesper Weithz (red.)

Det fackliga idéinstitutet Katalys sammanställning av hela sitt omfattande klassprojekt.

752 sidor klass- och samhällsanalys med studiehandledning och extra allt.

"Efter år av flum, associationer och fördomar i diskussionen om klass, har vi äntligen här en solid utgångspunkt. Av 640 sidor är det knappt någon som inte ger en ny insikt. Det är en otrolig gärning av Katalys att presentera den samlade spetsforskningen på detta lättfattliga sätt, med förslag i slutet för den som vill starta en studiecirkel. Jag skulle inte bli förvånad om vi redan här har årets bok."

- Kajsa Ekis Ekman i Aftonbladet

\section{"Läs mer om boken på www.arkiv.nu»}




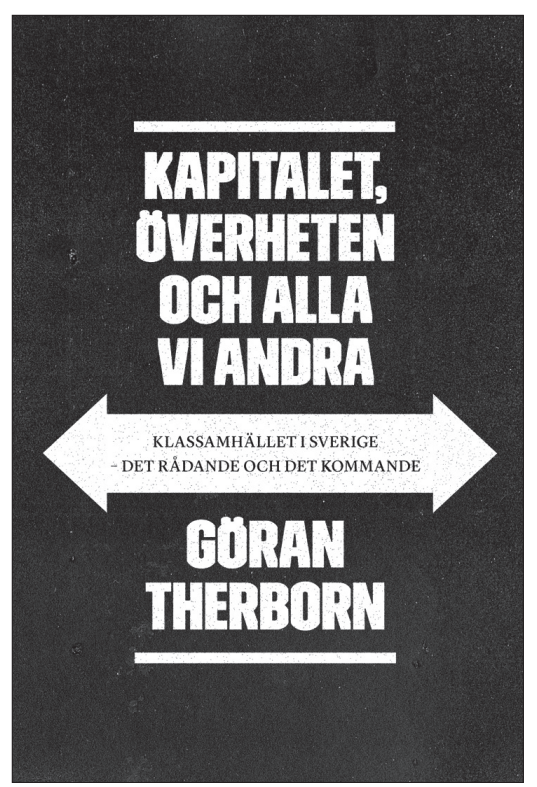

\section{OCH I VÄRLDEN}

Ojämlikhet dödar

2 I2 sidor

Göran Therborns internationella studie av ojämlikhetens dödliga effekter i såväl fattiga som rika länder (på engelska The Killing Fields of Inequality). Boken placerar in den svenska utvecklingen som tecknas i Kapitalet, överheten och alla vi andra i en global kontext.

Tillsammans skildrar de båda verken på ett klargörande sätt en av vår tids största ödesfrågor.

\section{GÖRAN THERBORN TAR SIG AN DEN SKENANDE OJÄMLIKHETEN I SVERIGE}

Kapitalet, överheten och alla vi andra. Klassambället i Sverige - det rådande och det kommande

$$
\text { I76 sidor }
$$

Therborns omtalade uppgörelse med det svenska klassamhället av idag.

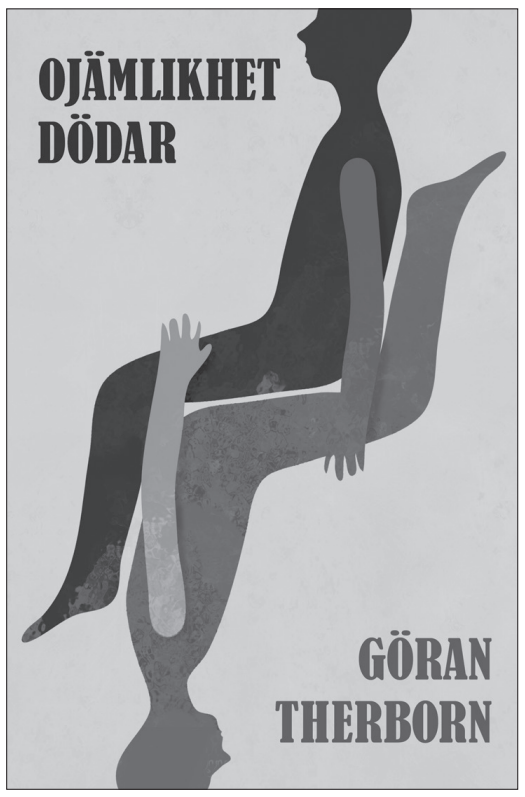

"BÖCKERNA GÅR ATT BESTÄLLA I BOKHANDELN OCH FRÅN WWW.ARKIV.NU» 